\title{
ANALISIS PENGARUH PERSPEKTIF DAN MOTIVASI PEGAWAI NEGERI SIPIL TERHADAP KARIR DI LEMBAGA KESEHATAN PENERBANGAN DAN RUANG ANGKASA (LAKESPRA SARYANTO) JAKARTA
}

\author{
Bambang B Sulistiyono ${ }^{1}$, Joko Supriyanto ${ }^{2}$ \\ Fakultas Ekonomi, Universitas Surya Dharma \\ email : bangsul_05@yahoo.co.id
}

\begin{abstract}
Abstrak. Badan Penerbangan dan Ruang Angkasa (LAKESPRA) Saryanto Jakarta adalah institusi yang memiliki peran strategis di bidang kedirgantaraan. yang memiliki tanggung jawab utama untuk melakukan pemeriksaan medis terhadap pesawat tempur militer dan sipil dan menjadi referensi ilmiah untuk komunitas penerbangan termasuk studi kesehatan di bidang ruang angkasa di Indonesia.

Lakespra dikelola oleh personil militer dan pegawai sipil yang keduanya memiliki peran dan tanggung jawab yang sama sejak kebijakan pelengkap diterapkan. Namun, pada kenyataannya pegawai negeri sampai sekarang semua bersemangat untuk mencapai kinerja tinggi, namun ditandai dengan rendahnya motivasi dan perspektif mereka dalam melihat masa depan karirnya. Hasilnya menunjukkan kelompok perempuan memiliki motivasi dan perspektif yang lebih baik mengingat masa depannya, yang mencapai $51 \%$ pria.

Demikian pula, kelompok S2 berpendidikan tinggi memiliki motivasi dan perspektif tertinggi dibandingkan dengan lulus DIII dan S1. Dari hasil penelitian tersebut memberikan skematik dan perspektif dan pemahaman bahwa faktor-faktor yang memotivasi memiliki peran penting dalam menunjang karir berkarir di Lakespra.
\end{abstract}

Kata kunci: Perspektif, Motivasi, Karir.

Abstract. Health Institute of Aeronautics and Space (LAKESPRA) Saryanto Jakarta is an institution that has a strategic role in the field of aerospace. which has primary responsibility for carrying out a medical examination of the crew military and civilian aircraft and became a scientific reference for the aviation community including health study in the field of space in Indonesia.

Lakespra staffed by military personnel and civilian employees who both have the same roles and responsibilities since the complement policies implemented. However, in reality civil servants until now all excited to achieve high performance, it is characterized by low motivation and their perspective in viewing the future of his career. The results showed the group of women had a better motivation and perspective in view of his future, which reached $51 \%$ of the men.

Similarly, a group of highly educated $\mathbf{S} 2$ has the highest motivation and perspective compared to the pass DIII and S1. From the results of the study provide a schematic and perspective and understanding that the factors motivating factors have a crucial role in supporting employee career at Lakespra.

Keywords: Perspective, Motivation, Career.

\section{PENDAHULUAN}

\section{Latar Belakang}

Dengan telah dimulainya pelaksanaan pengintegrasian sektor transportasi udara melalui kebijakan membuka wilayah udara atau Asean Open Sky Policy di kawasan negara-negara Asean pada era Masyarakat
Ekonomi Asean (MEA), tentu kebijakan tersebut memberikan dampak yang cukup kuat terhadap bidang-bidang perekonomian, terutama yang memiliki kompetensi dibidang pengelolaan kawasan kedirgantaraan serta usaha-usaha turunannya. Artinya kebijakan tersebut dapat menciptakan suatu dampak peluang yang potensial, namun juga menjadi 
ancaman yang potensial pula bagi para pelaku, perencana, serta penyelenggara kegiatan yang berhubungan dengan kegiatan kedirgantaraan di dalam negeri bila kita tidak cukup siap dalam menghadapinya. Bercermin dari kondisi tersebut, pada akhirnya untuk meraih keunggulan bersaing pada era globalisasi dewasa ini, tidak hanya dituntut adanya insfratruktur yang baik, namun juga menuntut adanya kemampupasaran sumber daya manusia dalam sebuah organisasi untuk dapat bersaing dan berkembang, tak terkecuali Lembaga Kesehatan Penerbangan dan Ruang Angkasa (Lakespra) Saryanto Jakarta. Lembaga tersebut memiliki peran yang strategis dibidang kedirgantaraan serta merupakan salah satu badan pelaksana teknis dari dinas kesehatan milik Tentara Nasional Indonesia Angkatan Udara (TNI-AU) yang mempunyai tugas utama melaksanakan pemeriksaan kesehatan bagi para awak pesawat terbang militer, awak pesawat terbang sipil, penyelenggaraan Indoktrinasi dan Latihan Aerofisiologi (ILA), pusat kesehatan masyarakat umum, serta menjadi rujukan ilmiah bagi masyarakat penerbangan termasuk kajian kesehatan pada bidang antariksa di Indonesia. Sumber daya manusia pada lembaga tersebut selain diawaki oleh para personel TNI AU, juga terdapat pegawai negeri sipil yang bekerja pada jabatan-jabatan struktural dan fungsional. Keberadaan pegawai negeri sipil di lembaga militer di Indonesia sudah menjadi suatu hal komplementer, artinya bahwa adanya suatu sifat kerja yang saling mengisi atau melengkapi diantara keduanya dan tidak dapat terpisahkan dalam melaksanakan kegiatan operasionalnya.

Perlu dipahami bersama, bahwa pegawai merupakan sumber daya terpenting dalam sebuah manajemen organisasi. Tanpa sumber daya manusia yang unggul, tentu sumber daya lainnya akan sulit beranjak dari statusnya dari sekadar kata potensi. Oleh karena itu pengelolaan sumber daya manusia merupakan langkah strategik dalam upaya menjalankan organisasi. Salah satu pendekatan yang dilakukan oleh organisasi tersebut ialah melalui manajemen karir yang merupakan bagian dari hasil keluaran manajemen sumberdaya manusia yang ditujukan kepada para pegawainya. Pendekatan tersebut bertujuan agar alokasi sumberdaya manusia dapat secara tepat memenuhi kebutuhan dan sasaran dalam hierarki organisasi.

Karier selain merupakan kebutuhan dalam kehidupan kerja seorang pegawai, juga merupakan sebagai sarana untuk menunjukkan kemampupasaran tenaga kerja. Pada umumnya orang-orang berpandangan bahwa aktivitas kerja yang dilakukannya diharapkan akan mampu membawanya kepada suatu keadaan yang lebih baik daripada keadaan yang sebelumnya. Harapan tersebut bukan hanya memperoleh kompensasi yang layak maupun lingkungan kerja yang nyaman saja, namun juga mengenai kepastian akan masa depannya melalui pencapaian karier.

Walaupun pada dasarnya karier itu bersifat ideal, artinya setiap pegawai dapat memiliki peluang yang sama dan siapapun dapat memilikinya. Namun untuk mencapainya tentu diperlukan penyesuaian kriteria yang dipersyaratakan oleh organisasi. Oleh karena itu, karier bukan hanya menjadi tanggungjawab organisasi semata, namun juga menjadi tanggungjawab setiap diri individu pegawai. Merujuk masalah tersebut, tentu bagi pegawai haruslah memiliki upayaupaya untuk mencapainya. Tidak semua pegawai menyadari dan memiliki pandangan bahwa melalui saluran karir seorang pegawai dapat menunjukkan eksistensinya dalam bersaing, atau seringkali pegawai hanya memiliki keinginan untuk memiliki suatu karier tertentu, namun keinginan itu kurang didukung adanya suatu pengupayaan yang mendukungnya. Seringkali seorang pegawai yang sebenarnya memiliki potensi untuk berkembang, namun hal tersebut berada jauh di atas yang disadarinya. Permasalahan tersebut juga muncul karena para pegawai kemungkinannya tidak cukup termotivasi untuk mencapainya. 
Bambang B Sulistiyono, Joko Supriyanto, Analisi Pengaruh Perspektif dan Motivasi Pegawai...

\section{Rumusan Masalah}

Berangkat dari pemaparan tersebut, maka dapat diidentifikasi adanya suatu gejala atau permasalahan mengenai kaitannya faktor perspektif dan faktor motivasi terhadap karir pegawai negeri sipil di Lakespra Saryanto yang perlu dilakukan penelitian lebih lanjut.

Adapun perumusan masalah sebagai berikut: (1). Apakah Perspektif berpengaruh terhadap karir. (2). Apakah motivasi berpengaruh berpengaruh terhadap karir. (3). Apakah perspektif dan motivasi secara bersama-sama berpengaruh terhadap karier.

\section{Tujuan Penelitian}

Berdasarkan rumusan tersebut, maka tujuan penelitiannya adalah: (1). Untuk mengetahui pengaruh perspektif terhadap karir. (2). Untuk mengetahui pengaruh motivasi terhadap karir. (3). Untuk mengetahui pengaruh perspektif dan motivasi secara bersama-sama terhadap karir. Untuk menunjukkan minat tunggal, maka fokus daripada penelitian ini adalah pegawai negeri sipil yang bekerja di Lakespra Saryanto.

\section{Kajian Literatur}

Menurut Fisher (Ardianto dan Q-Anees, 2014: 75), perspektif adalah sudut pandang dan cara pandang kita terhadap sesuatu. Menurut Ardianto dan Q-Anees (2014:77), menggunakan perspektif berarti menyadari bahwa suatu pemahaman selalu dibangun oleh kait kelindan antara apa yang diamati dan apa yang menjadi konsep pengamatan. Dengan adanya perspektif pada diri pegawai, akan memberikan skema atau petunjuk mengenai sudut pandang mana yang akan dipilih dan digunakan dalam memaknai suatu obyek.

Konsekuensi pada penggunaan perspektif adalah apa yang dilihat sekarang bukanlah kebenaran yang mutlak, melainkan sebuah pemahaman yang dicipkatan oleh diri sendiri. Terkadang sudut pandang yang kita gunakan ternyata kurang tepat, dan selanjutnya mencoba mencari sudut pandang lainnya atau membangun perspektif baru. Hal inilah yang perlu disadari bahwa sudut pandang merupakan produk dari manusia, maka sudut pandang biasanya tunduk hanya pada konseptual pengetahuan atau pengalaman yang dimilikinya saja. Oleh karena itu, sudah sepantasnya pegawai dalam bekerja selalu terus berusaha menggapai apa yang telah direncanakan dan yang diinginkan untuk suatu tujuan dalam organisasi. Rakhmat (2011:30), manusia bukan saja sekadar mahluk yang berfikir, namun juga berusaha menemukan identitas dirinya dan mencapai apa yang didambakannya. Menurut Ardianto dan Q Anees (2014: 151), setiap pernyataan pandangan pada dasarnya adalah merupakan tindakan penciptaan makna, tindakan pembentukan diri serta pengungkapan jati diri. Pernyataan tersebut memberikan petunjuk adanya beberapa poin penting yang dapat dijadikan sebagai pengukuran mengenai perspektif seseorang.

Hal yang cukup mendasar, bahwa keberhasilan dalam pekerjaan tidaklah terlepas dari unsur kekuatan daya pemikiran yang kuat serta kemampuan merefleksikan antara apa yang terbangun dalam pikirannya dengan apa yang akan dilakukan dalam mencapai suatu tujuan tertentu. Hal tersebut ditegaskan oleh Suryana (2006: 42), orangorang yang memiliki orientasi ke masa depan adalah orang yang memiliki perspektif, karena memiliki pandangan jauh kedepan maka seseorang itu akan berusaha untuk berkarya. Pernyataan tersebut memperjelas bahwa perspektif memiliki arah yang sangat penting dalam rangka menjaga fokus cara berpikir pegawai untuk menjalankan tugas pokok dan fungsinya sebagai bagian dari motoris operasional dari suatu organisasi.

Motivasi menurut Mangkunegara (2013: 93), bahwa motif merupakan suatu dorongan kebutuhan dalam diri pegawai yang perlu dipenuhi agar pegawai tersebut dapat menyesuaikan diri terhadap lingkungannya, sedangkan motivasi adalah kondisi yang menggerakkan pegawai agar mampu mencapai tujuan dari motifnya. Kemudian menurut Sarlito (2010: 137), adalah seluruh proses gerakan yang timbul dari individu dan perilaku yang ditimbulkan oleh situasi atau lingkungan. Alur terjadinya proses motivasi dapat digambarkan sebagai berikut: 


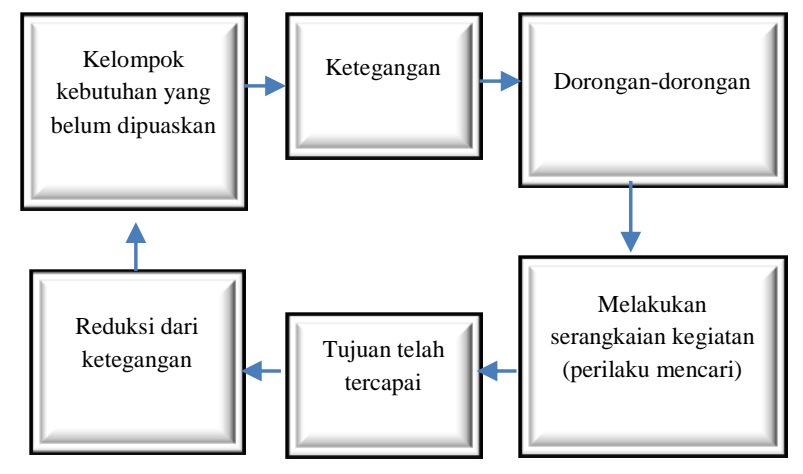

Sumber: Munandar (2014: 323)

\section{Gambar 1. Proses Motivasi}

Dari gambar tersebut, jelas motivasi tidak lepas dari adanya suatu unsur kebutuhan yang ingin dipenuhi oleh setiap orang. Abraham Maslow (Munandar, 2014: 326), kondisi manusia berada dalam kondisi mengejar yang berkesinambungan. Jika satu kebutuhan dipenuhi, langsung kebutuhan tersebut diganti oleh kebutuhan lain. Proses berkeinginan secara nonstop memotivasi kita sejak lahir sampai meninggal. Hipotesis yang diajukan oleh Abraham Maslow (Umam: 2010) mengenai tata tingkat kebutuhan manusia adalah terdiri dari: (1). Kebutuhan fisiologikal (2). Kebutuhan rasa aman (3). Kebutuhan sosial (4). Kebutuhan harga diri, dan (5). Kebutuhan aktualisasi diri.

Menurut Hasibuan (2009: 141), motivasi dalam manajemen hanya ditujukan pada sumber daya manusia umumnya dan bawahan khususnya. Perlu dipahami bahwa pada umumnya suatu tujuan akan tercapai dengan lebih optimal bila ada daya motivasi yang kuat dari diri seseorang. Hal tersebut selaras dengan apa yang diungkapkan oleh Umam (2010: 159), bahwa kuat dan lemahnya motivasi kerja seseorang ikut menentukan besar kecilnya prestasi orang terebut. Pernyatan tersebut memberikan suatu pemahaman bahwa bila seseorang ingin mendapatkan pemenuhan kebutuhannya, maka daya motivasi yang dikeluarkannya akan mengikuti seberapa besar tingkat hasil yang diperolehnya. Menurut Mclelland (Hasibuan, 2009: 162), bahwa karyawan mempunyai cadangan energi potensial. Bagaimana energi dilepaskan tergantung pada kekuatan motivasi seseorang yang didorong oleh : (1). Kekuatan motif dan kebutuhan dasar yang terlibat (2). Harapan keberhasilan (3). Nilai insentif yang terlekat pada tujuan.

Karier menurut Handoko (2011: 121), adalah semua pekerjaan atau jabatan yang dipunyai atau dipegang selama kehidupan kerja seseorang. Supaya karier seorang pegawai dapat berkembang, maka diperlukan suatu perencanaan. Perencanaan karir menurut Simamora (2014: 112), adalah proses yang dilalui oleh individu karyawan untuk mengidentifikasi dan mengambil langkahlangkah untuk mencapai tujuan karirnya. Begitu pentingnya suatu perencaan karir, dikarenakan banyak pegawai gagal mengelola karir dikarenakan kurangnya memiliki perencanaan karir. Permasalahan tersebut diperkuat dengan apa yang dinyatakan oleh Handoko (2011: 123), bahwa banyak orang gagal mengelola karir, karena mereka tidak memperhatikan konsep-konsep dasar perencanaan karir. Memang perencanaan karir tidak serta merta menjamin karir seseorang akan berkembang, namun dengan adanya perencanaan karier setidaknya tujuan karir lebih cenderung tercapai.

Pengembangan karir menurut Rivai (2015: 212), adalah proses peningkatan kemampuan kerja individu yang dicapai dalam rangka mencapai karier yang diinginkan. Hubungan perencanaan karir dan pengembangan karir menurut Marlia dan Hidayat (Fajar dan Heru, 2015: 128), pengembangan karir adalah proses pelaksanaan atau implementasi dari perencanaan karier. Hubungan antara perencanaan dan pengembangan karir tersebut sebagaimana pada kerangka gambar di bawah ini:

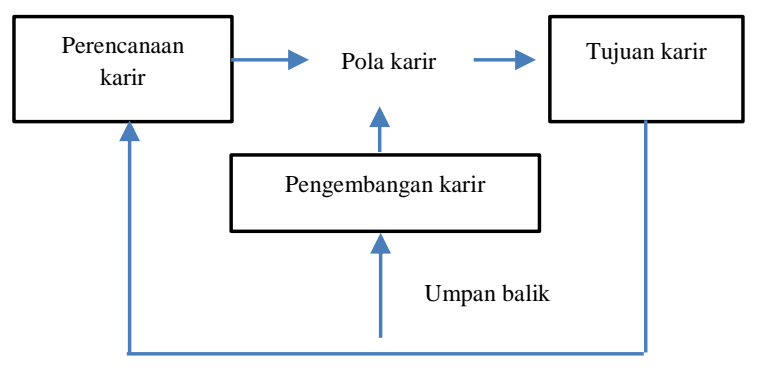

Sumber: Rivai (2015: 218) 
Bambang B Sulistiyono, Joko Supriyanto, Analisi Pengaruh Perspektif dan Motivasi Pegawai...

\section{Gambar 2. Perencanaan dan Pengembangan Karir}

Berdasarkan gambar tersebut, maka ada suatu peranan dari organisasi yang cukup penting, yaitu umpan balik. Dimana tanpa adanya umpan balik dari organisasi dalam hal ini bagian kepersonaliaan, maka sangat sulit bagi karyawan untuk mengetahui titik posisinya. Hal tersebut selaras dengan pendapat Rivai (2015: 218), tanpa umpan balik sangat sulit bagi karyawan untuk mengetahui prestasi atau kekurangan atas pekerjaan yang dilakukannya.

Efektivitas karier menurut Simamora (2014: 412), dinilai dalam kondisi seperti apakah karyawan akan menyatakan bahwa karirnya memuaskan atau berhasil, yaitu terdiri dari empat karakteristiknya yaitu: 1). Kinerja karier Gaji dan posisi merupakan indikator paling popular dari kinerja karier. 2). Sikap karir Konsep sikap karier mengacu pada cara individu melihat dan mengevaluasi kariernya. 3). Adaptabilitas karier, Adaptabilitas karier adalah lebih menekankan pada suatu upaya menyesuaikan diri kita dengan perkembangan jaman. Karena jika tidak mampu beradaptasi, maka akan menanggung risiko keusangan dan kehilangan pekerjaan. 4) Identitas karier, mencakup tingkat kesadaran yang konsisten menyangkut minat, nilai, nilai, ekpektasi mereka dimasa depan, serta kepuasan kerja.

Begitu pentingnya pemberdayaan sumber daya manusia dalam sebuah organisasi, maka pengelolaan pegawai negeri sipil juga dimaksudkan agar tercapainya tujuan organisasi melalui pendayagunaan aparatur sipil negara. Menurut Daryanto dan Abdullah (2013: 202), manajemen pegawai negeri sipil adalah keseluruhan upaya untuk efisiensi, efektivitas, dan derajat keprofesionalisme penyelenggaraan tugas, fungsi dan kewajiban kepegawaian yang meliputi perencanaan, pengadaan, pengembangan kualitas, penempatan promosi, penggajian, kesejahteraan, dan pemberhentian.

Adanya pegawai negeri sipil di lingkungan militer di Indonesia pada dasarnya sesuai dengan Peraturan Menteri Pertahanan
Nomor 22 tahun 2010 Pasal 1 ayat 2 yang berbunyi: Pegawai Negeri Sipil Kementrian Pertahanan selanjutnya disingkat PNSKemhan, adalah Pegawai Negeri Sipil yang bertugas dilingkungan unit organisasi Kemhan yang dipekerjakan di UPN "Veteran", unit organisasi Mabes TNI, unit organisasi TNI AD, unit organisasi TNI AL, dan unit organisasi TNI AU.

Dari uraian permasalahan dan tinjauan pustaka, maka diperoleh sintesa kerangka berfikir sebagai berikut:

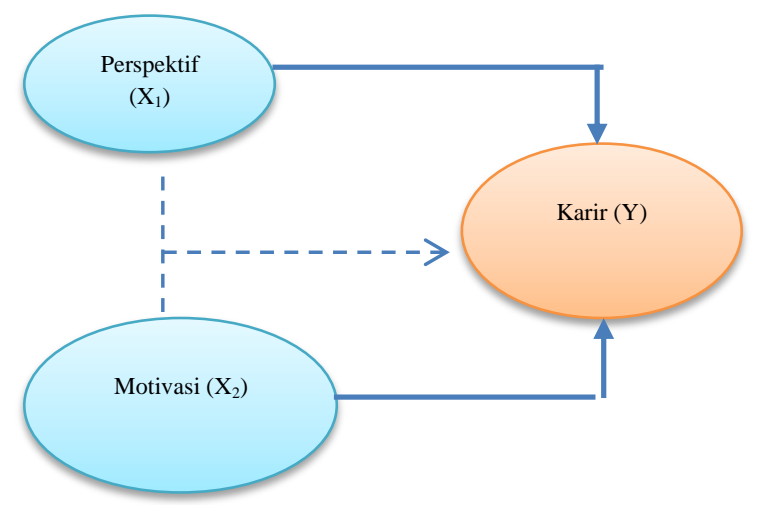

Gambar 3. Kerangka berpikir

Keterangan:

$\rightarrow$ Pengaruh secara parsial perspektif dan motivasi terhadap karir.

$-\rightarrow$ Pengaruh secara simultan perspektif dan motivasi terhadap karir.

Berdasarkan alur glayutan pemikiran yang didasarkan pada permasalahan dan kajian teoritis antara faktor perspektif dan faktor motivasi pegawai terhadap karier, maka hipotesis yang diajukan adalah:

$\mathrm{H}_{1}$ : Secara parsial perspektif berpengaruh positif dan signifikan terhadap karir pegawai.

$\mathrm{H}_{2}$ : Secara parsial motivasi berpengaruh positif dan signifikan terhadap karir pegawai.

$\mathrm{H}_{3}$ : Secara bersama-sama perspektif dan motivasi berpengaruh positif dan signifikan terhadap karir pegawai.

\section{METODE PENELITIAN}

Metode penelitian menggunakan pendekatan kuantitatif survei dengan maksud untuk memperoleh informasi yang dapat menjeneralisir hasil penelitian. Dimana untuk menjawab rumusan masalah digunakan 
berbagai teori yang sesuai, sehingga dapat diajukan hipotesis. Variabel dalam penelitian ini dibagi menjadi dua jenis yaitu: (1). Variabel independen yang terdiri dari variabel perspektif yang diberi simbol $\mathrm{X}_{1}$ dan variabel motivasi yang diberi simbol $\mathrm{X}_{2}$. (2). Variabel dependen yaitu variabel karier yang diberi simbol Y.

Penelitian dilaksanakan di Lembaga Kesehatan Penerbangan dan Ruang Angkasa (Lakespra) Saryanto, yang beralamat di Jalan M.T. Haryono kavling 23 Jakarta, tahun 2016. Pengumpulan data dilakukan melalui penyebaran kuesioner yang dijadikan sebagai data primer dengan mengambil sampel sebanyak 61 responden dari 71 pegawai negeri sipil yang bekerja di Lakespra Saryanto. Untuk mengungkap setiap variabel yang diteliti, maka pengukurannya diukur dengan menggunakan instrumen dari masingmasing variabel dengan menggunakan skala likert dari kriteria jawaban terendah dengan skor 1 hingga tertinggi skor 5. kemudian data diolah secara statistik untuk kemudian dianalisis atau diinterprestasikan.

Teknik analisis data menggunakan tehnik regresi linear berganda dengan didahului uji-uji asumsi regresi seperti: (1) Uji normalitas, (2). Uji linearitas, (3). Uji homogenitas,(4). Uji multikolinearitas (5). Uji heteroskedastisitas. Sedangkan untuk menguji hipotesis secara parsial digunakan uji t dan untuk uji secara simultan menggunakan uji $\mathrm{F}$ dan taraf signifikansinya. Berdasarkan hasil persamaan regresi linear berganda, maka akan dijadikan sebagai instrumen untuk meramalkan atau memprediksi perubahan yang akan terjadi pada variabel terikat atas perubahan atau pengaruhnya dari variabel bebas. Pengolahan data dilakukan dengan menggunakan bantuan program Software Statistic Package and Social Sciene Version 22 For Windows.

\section{HASIL PENELITIAN DAN PEMBAHASAN}

Pegawai negeri sipil dilingkungan Lakespra Saryanto direkrut melalui penyeleksian yang dilakukan oleh Kementrian
Pertahanan dan ditugaskan di badan pelaksana teknis unit kesehatan TNI AU. Umumnya mereka bekerja pada berbagai bidang jabatan fungsional sebagai Dokter, Perawat, Adminitrasi, serta jabatan lainnya. Adapun karakteristik responden yang telah dihimpun dapat dilihat pada tabel dibawah ini:

Tabel 1.

Karakteristik Responden

\begin{tabular}{|c|c|c|c|}
\hline $\begin{array}{c}\text { Jenis } \\
\text { Kelamin }\end{array}$ & $\begin{array}{c}\text { Usia } \\
\text { (tahun) }\end{array}$ & Pendidikan & Golongan \\
\hline $\begin{array}{c}\text { Laki-laki } \\
19 \text { orang } \\
31 \%\end{array}$ & $\begin{array}{c}21-30 \\
14 \\
\text { orang } \\
23 \%\end{array}$ & $\begin{array}{c}\text { SLTA } \\
19 \text { orang } \\
31 \%\end{array}$ & $\begin{array}{c}\text { II } \\
26 \text { orang } \\
42 \%\end{array}$ \\
\hline \multirow[t]{3}{*}{$\begin{array}{c}\text { Perempuan } \\
42 \text { orang } \\
69 \%\end{array}$} & $\begin{array}{c}31-40 \\
29 \\
\text { orang } \\
47 \%\end{array}$ & $\begin{array}{c}\text { D-III } \\
25 \text { orang } \\
41 \%\end{array}$ & $\begin{array}{c}\text { III } \\
31 \text { orang } \\
51 \%\end{array}$ \\
\hline & $\begin{array}{c}41-50 \\
14 \\
\text { orang } \\
23 \%\end{array}$ & $\begin{array}{c}\text { S-1 } \\
15 \text { orang } \\
25 \%\end{array}$ & $\begin{array}{c}\text { IV } \\
4 \text { orang } \\
7 \%\end{array}$ \\
\hline & $\begin{array}{c}51-60 \\
4 \\
\text { orang } \\
7 \%\end{array}$ & $\begin{array}{c}\text { S-II } \\
2 \text { orang } \\
3 \%\end{array}$ & \\
\hline
\end{tabular}

Sumber: Lakespra Saryanto (2016)

Berdasarkan tabel tersebut diketahui bahwa sebesar $69 \%$ mayoritas pegawai negeri sipil yang bekerja di Lakespra Saryanto adalah berjenis kelamin perempuan. Sedangkan jika dilihat dari sisi usia pegawai, terlihat bahwa pada umumnya para pegawai berusia $31-41$ tahun dengan persentasi sebesar $47 \%$. Sementara menurut jenjang pendidikan, terlihat bahwa lebih banyak pegawai memiliki jenjang pendidikan Diploma III dengan persentasi sebesar $41 \%$. 
Bambang B Sulistiyono, Joko Supriyanto, Analisi Pengaruh Perspektif dan Motivasi Pegawai...

Kemudian jika dilihat dari segi golongan pegawai, tampak bahwa pada umumnya pegawai yang bergolongan III yang lebih mendominasi komposisi pegawai negeri sipil di Lakespra Saryanto.

Hasil pengujian hipotesis, menghasilkan nilai persamaan regresi berganda sebagai berikut:

$\mathrm{Y}=-4.360+0.376 \mathrm{x}_{1}+0.400 \mathrm{x}_{2}$

Berdasarkan hasil persamaan regresi linear berganda tersebut, maka analisisnya bahwa nilai konstanta sebesar -4.360 yang memiliki makna bahwa jika pegawai tidak memiliki atau mengabaikan faktor perspektif dan motivasi dalam bekerja, maka kariernya akan negatif atau kehilangan kesempatan untuk meraih karier tertentu. Nilai koefisien regresi perspektif sebesar 0.376 dengan $t_{\text {hitung }}$ 3.578 pada tingkat signifikansi sebesar 0.001 . Hal tersebut membuktikan bahwa secara parsial perspektif pegawai berpengaruh positif dan signifikan terhadap karir. Selanjutnya perolehan nilai koefisien regresi variabel motivasi 0.400 dengan $t_{\text {hitung }} 4.156$ pada tingkat signifikansi sebesar 0.000 , memiliki makna bahwa secara parsial motivasi pegawai berpengaruh positif dan signifikan terhadap karir. Sedangkan pengaruh secara simultan diperoleh nilai $F_{\text {hitung }} 42.131$ dengan tingkat signifikansi 0.000 yang memiliki makna bahwa secara bersama-sama perspektif dan motivasi pegawai berpengaruh positif dan signifikan terhadap karir.

Untuk mengukur ketepatan fungsi regresi sampel dalam menaksir nilai aktual terhadap populasi, maka diketahui bahwa sebesar $59.2 \%$ variabel karier dapat dijelaskan oleh variabel perspektif dan variabel motivasi. Atau dengan kata lain, secara bersama-sama faktor perspektif dan faktor motivasi memiliki pengaruh terhadap karir sebesar $59.2 \%$ dan sisanya $40.8 \%$ disebabkan faktor lain di luar model yang diteliti. Bila besaran sumbangan pengaruh secara simultan tersebut digambarkan, maka akan terlihat sebagaimana diagram berikut ini:

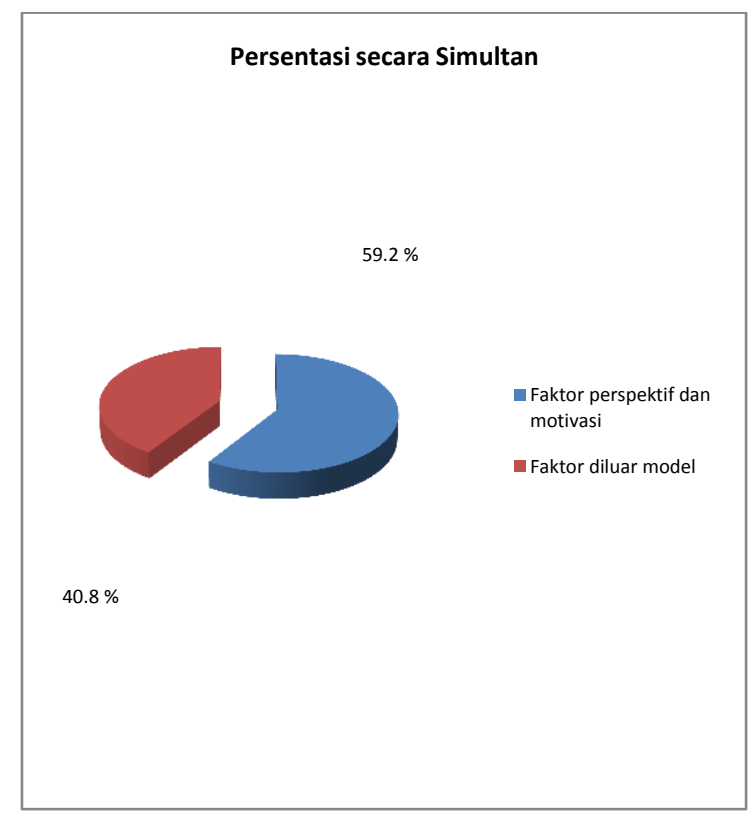

Gambar 4. Sumbangan Pengaruh Secara Simultan

Untuk mengetahui besaran sumbangan variabel perspektif terhadap variabel karier, dan variabel motivasi terhadap variabel karir secara parsial, maka dapat dilihat sebagaimana gambar diagram berikut ini:

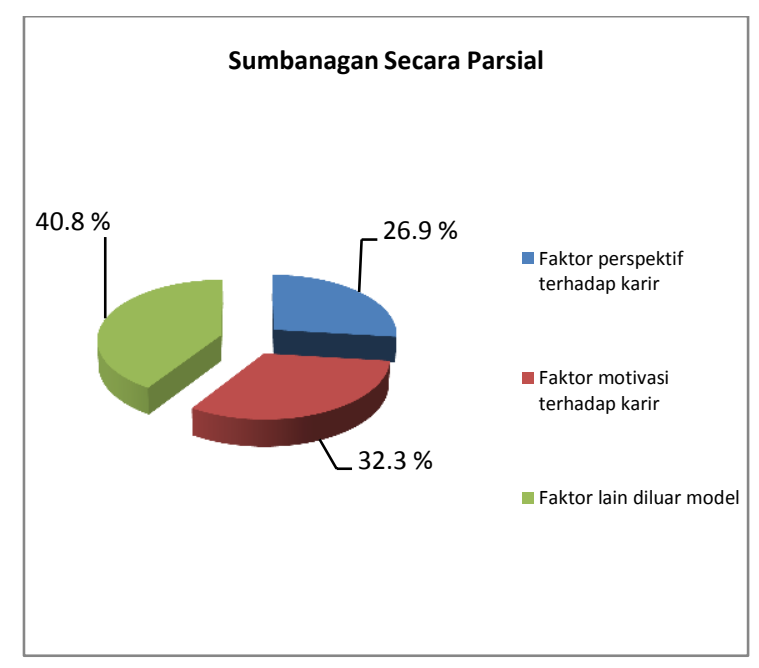

\section{Gambar 5. Sumbangan Pengaruh Secara Parsial}

Berdasarkan gambar diagram diatas tersebut, terlihat bahwa antara variabel bebas yaitu perspektif dan motivasi pegawai negeri sipil dilingkungan Lakespra Saryanto, diketahui bahwa faktor motivasi memiliki sumbangan pengaruh yang lebih besar $32.3 \%$ dibandingkan dengan faktor perspektif yang hanya memiliki pengaruh sebesar $26.9 \%$. 
Dari hasil penelitian yang telah dilakukan, menunjukkan bahwa secara umum perspektif pegawai negeri sipil di Lakespra Saryanto dapat dikatakan sudah baik. Namun demikian diketahui bahwa banyaknya tugas berdampak baik sebagai pengkayaan pengalaman, memiliki nilai tanggapan paling rendah, yaitu sebesar 4.02 dari nilai 5.00 yang diharapkan. Namun demikian tanggapan tersebut masih masuk dalam kategori baik, artinya para pegawai memandang bahwa ketika organisasi memberikan suatu tugas yang banyak, para pegawai memandang bahwa tugas tersebut dianggap sebagai suatu cara untuk pengkayaan pengalaman mereka. Hal itu selaras dengan apa yang dinyatakan oleh O'Connor dan Chamberlain (Umam, 2010:92), bahwa pengalaman merupakan dimensi yang penting dalam menggambarkan nilai diri seseorang.

Untuk melihat bagaimanakah perspektif pegawai negeri sipil di Lakespra Saryanto, berikut ini adalah visualisasi data yang diperoleh:

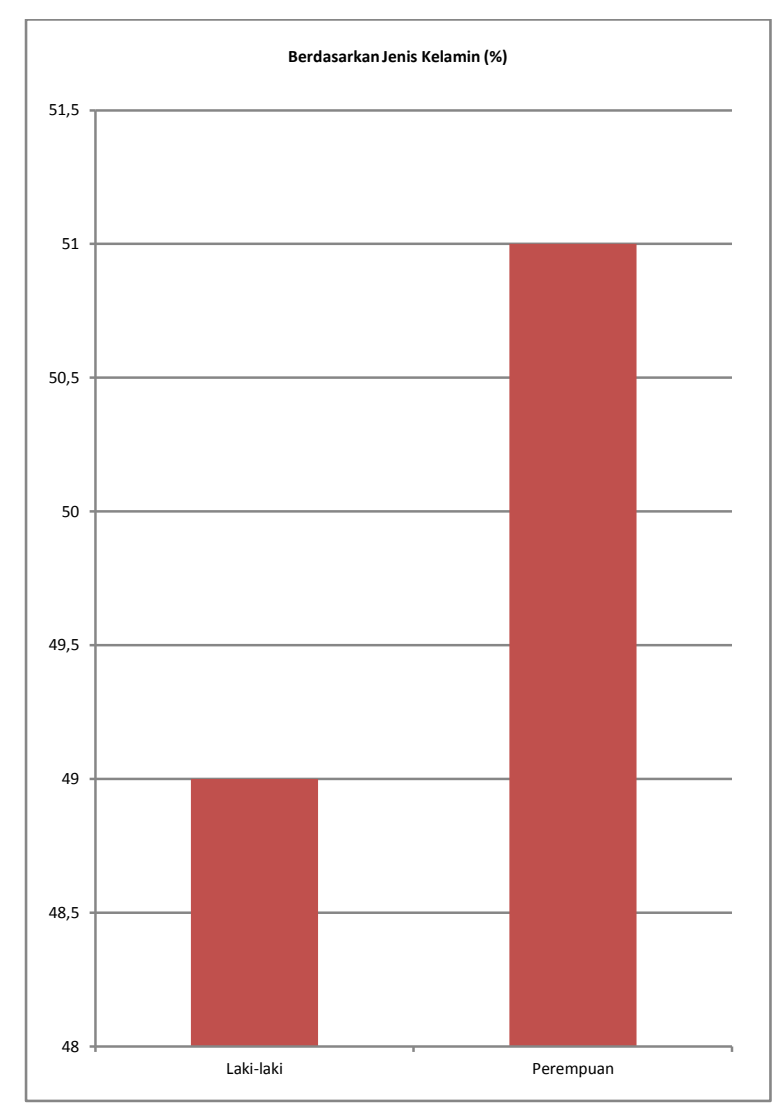

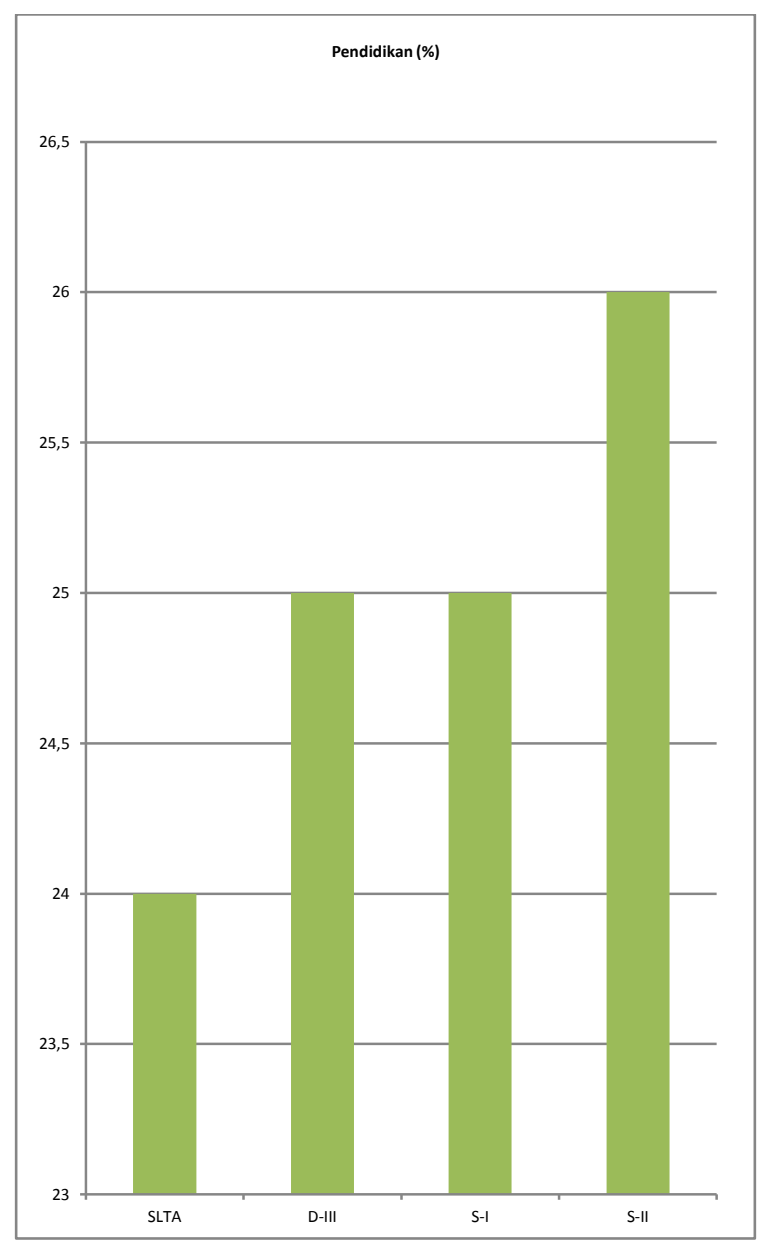

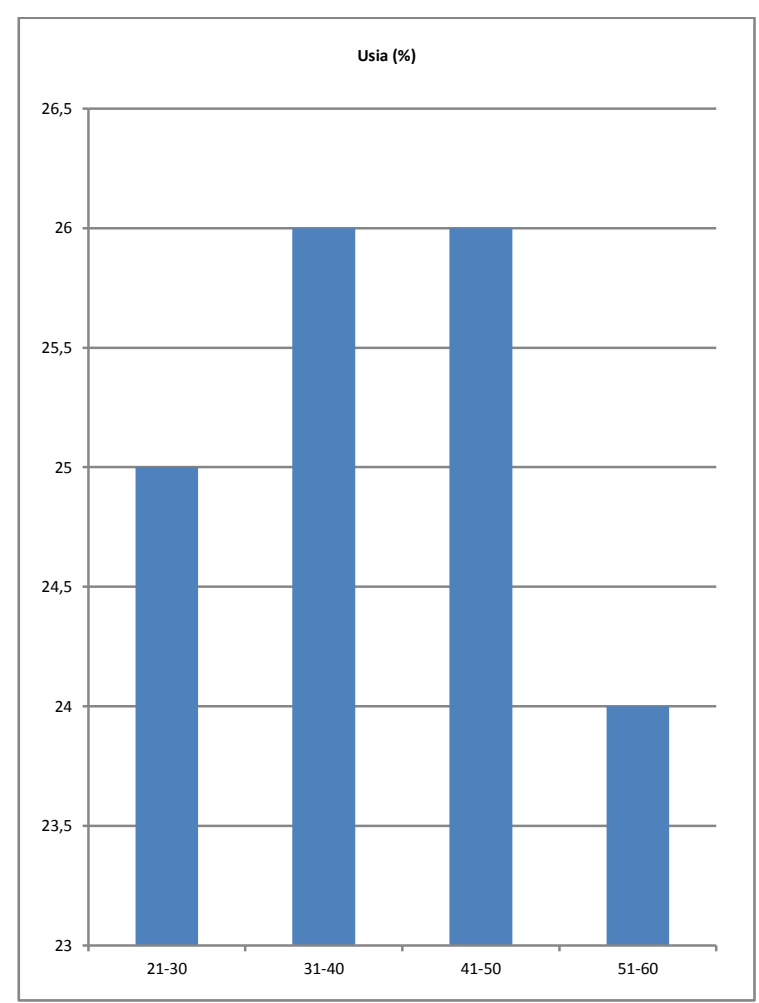


Bambang B Sulistiyono, Joko Supriyanto, Analisi Pengaruh Perspektif dan Motivasi Pegawai...

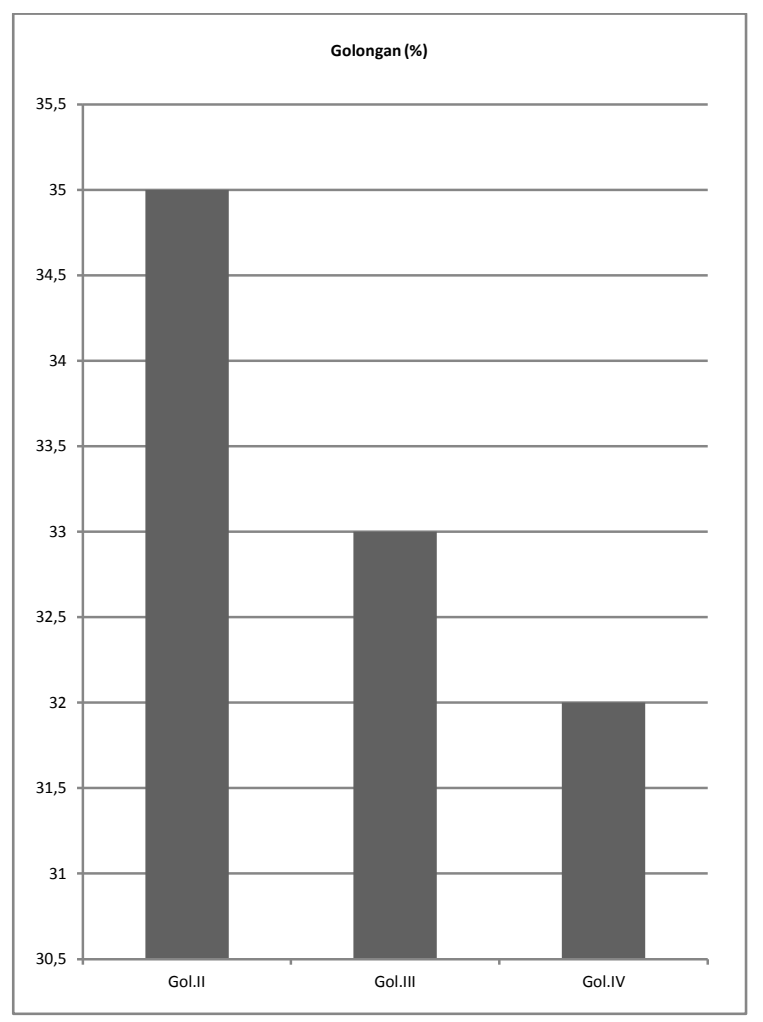

\section{Gambar 6. Perspektif Berdasarkan Karakteristik Pegawai}

Berdasarkan gambar grafik di atas, diketahui bahwa pegawai perempuan lebih memiliki nilai perspektif yang lebih tinggi, yaitu sebesar $51 \%$ dibanding pegawai yang bergender laki-laki yang hanya sebesar $49 \%$. Perbedaan tersebut menunjukkan bahwa pegawai perempuan mampu bersaing dan menunjukkan eksistensinya dengan pegawai laki-laki. Dilihat berdasarkan usia, terlihat bahwa perspektif pegawai membentuk seperti suatu siklus melengkung, bahwa nilai perspektif diawali dengan nilai perspektif pegawai yang berusia 21-30 tahun sebesar 25 $\%$, lalu pegawai dengan usia 31-40 tahun dan 41-50 tahun sebesar $26 \%$, dan pegawai yang berusia usia 31-40 tahun sebesar $24 \%$. Hasil penelitian tersebut menunjukkan bahwa perspektif terbaik dimiliki pegawai yang berusia 31-50 tahun. Selanjutnya berdasarkan pendidikan, diperoleh hasil bahwa pegawai dengan tingkat pendidikan S2 memiliki perspektif tertinggi, diikuti oleh pegawai yang berpendidikan $\mathrm{S}$ 1, dan terakhir pegawai yang memiliki pendidikan SLTA. Hasil tersebut memberikan suatu pemahaman bahwa, semakin tinggi pendidikan seseorang, maka cara atau pola berpikirnya akan semakin baik pula. Sedangkan perspektif pegawai dilihat dari segi golongan, maka tampak tidak berbanding lurus dengan tingkat golongan pegawai, karena pegawai yang bergolongan II memilki nilai perspektif yang paling tinggi, yaitu sebesar $35 \%$, kemudian diikuti golongan III sebesar $33 \%$, dan yang terakhir adalah golongan IV sebesar $32 \%$. Hal yang cukup membuat perbedaannya adalah mengenai penggunaan pendapat orang lain, dimana umumnya golongan II dan III masih memerlukan pendapat orang lain dalam menyelesaikan persoalan kerja, sedangkan golongan IV kurang begitu membutuhkan pendapat orang lain.

Dari hasil-hasil penelitian tersebut memberikan suatu pemahaman bahwa, walaupun pengaruh faktor perspektif terbilang relatif kecil terhadap karier, namun faktor tersebut terbukti memiliki peranan yang sangat penting sekali terhadap keberhasilan karier pegawai. Pentingnya perspektif dalam bekerja tersebut selaras dengan apa yang dikatakan oleh Suryana (2006: 42), bahwa orang-orang yang memiliki orientasi kemasa depan adalah orang yang memiliki perspektif, karena memiliki pandangan jauh ke depan maka seseorang itu akan berusaha untuk berkarya.

Mengenai motivasi, secara umum motivasi pegawai negeri sipil di lingkungan Lakespra Saryanto sudah baik. Hal tersebut dikarenakan adanya beberapa faktor kebutuhan yang sudah terpenuhi seperti, keamanan atau jaminan ekonomi ketika memasuki usia pensiun, sesama rekan kerja saling menerima pertemanan, pegawai dilibatkan dalam diskusi-diskusi didalam divisinya, dan para atasan pada umumnya selalu memberikan penghargaan berupa pujian ketika pegawai mampu menyelesaikan pekerjaan tepat pada waktunya.

Namun demikian, dari hasil penelitian ditemukan bahwa para pegawai masih kurang termotivasi dalam hal keinginan untuk menduduki posisi jabatan tertentu. Hal tersebut didasarkan pada tanggapan responden mengenai keinginan untuk menduduki posisi tertentu di Lakespra Saryanto yang memiliki tanggapan paling rendah di antara butir-butir pertanyaan 
lainnya yaitu sebesar 3.34 dari nilai 5.00 yang diharapkan, dan nilai tanggapan tersebut masuk dalam kategori kurang setuju. Artinya sebagian besar pegawai masih kurang berminat atau kurang terdorong untuk menempatkan dirinya pada jabatan-jabatan tertentu yang ada di Lakespra Saryanto. Selain itu faktor gaji masih dianggap oleh sebagian besar pegawai belum mampu mencukupi kebutuhannya pada saat ini. Tentu hasil temuan tersebut akan turut memberikan dampak kurang maksimalnya daya motivasi pegawai yang akan berpengaruh terhadap kurang maksimalnya kinerja karir yang telah direncanakan atau dirancang oleh para pegawai. Kemudian bila dicermati lebih mendalam lagi, maka akan diketahui berbagai informasi mengenai seperti apakah motivasi pegawai negeri sipil di Lakespra Saryanto.

Berikut ini adalah hasil pengolahan data yang disajikan dalam bentuk visualisasi gambar grafik mengenai motivasi pegawai:

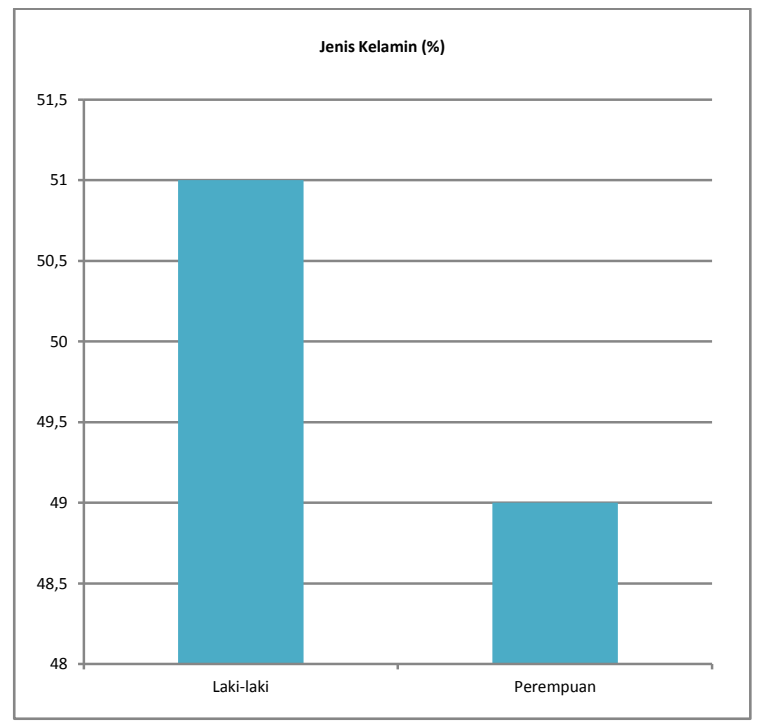

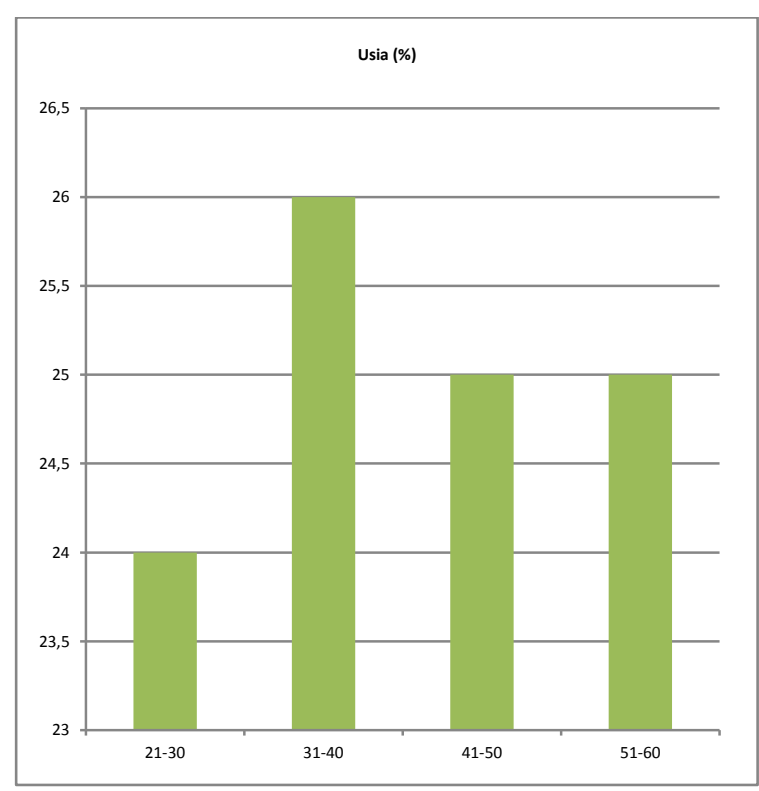
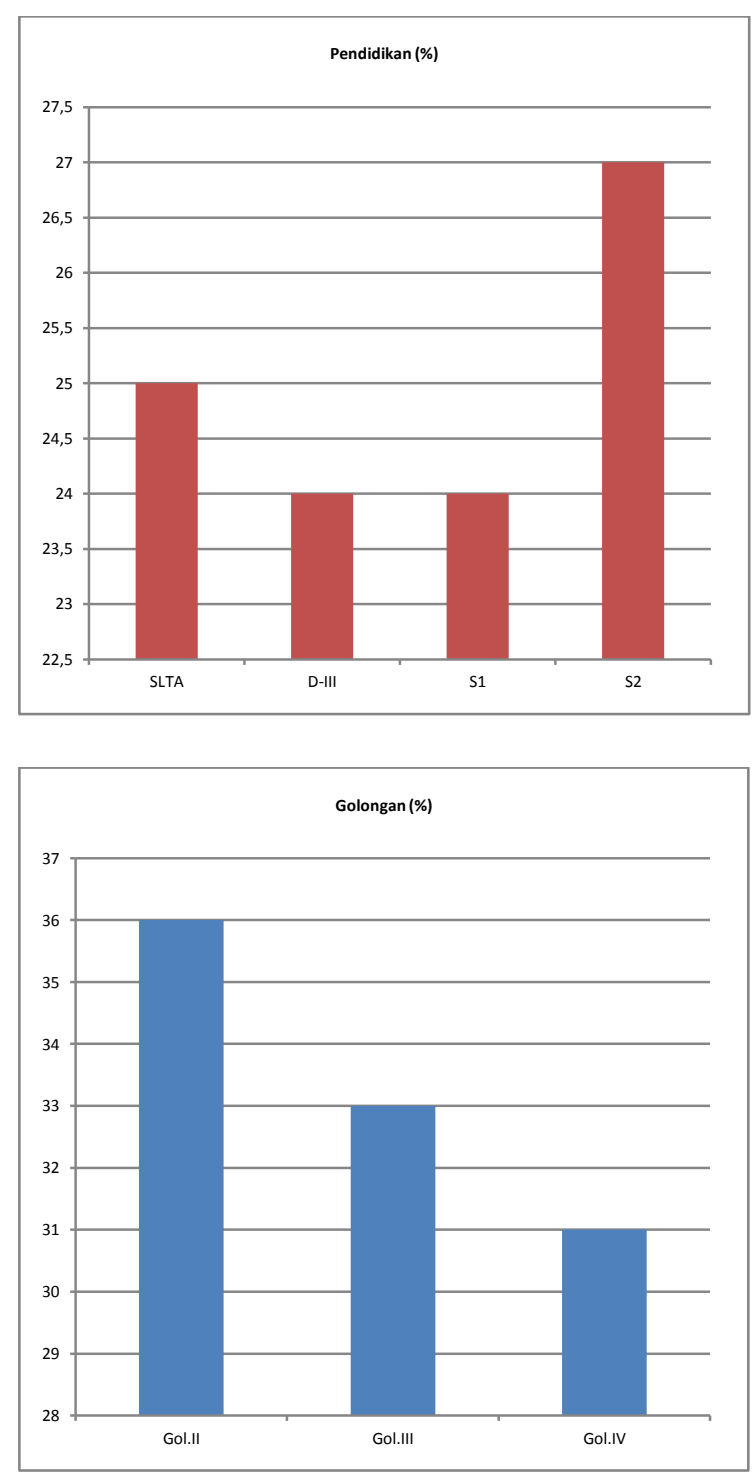

Gambar 7. 
Bambang B Sulistiyono, Joko Supriyanto, Analisi Pengaruh Perspektif dan Motivasi Pegawai...

\section{Motivasi Berdasarkan Karakteristik Pegawai}

Mengacu pada gambar grafik diatas tersebut, diketahui bahwa pegawai perempuan memiliki daya motivasi lebih tinggi yaitu sebesar $51 \%$ dibanding pegawai laki-laki yang sebesar $49 \%$. Jika dilihat dari sisi usia pegawai, maka tampak bahwa pegawai yang berusia 21-30 tahun memiliki motivasi yang terendah yaitu sebesar $24 \%$, dan pegawai dengan usia 31-40 tahun memiliki motivasi yang tertinggi yang mencapai $26 \%$. Sedangkan pegawai yang berusia 41-50 tahun dan 51-60 tahun motivasinya sebesar $25 \%$. Dari segi pendidikan diperoleh hasil, bahwa pegawai dengan pendidikan S2 memiliki motivasi yang paling tinggi yaitu sebesar 27 $\%$, kemudian yang berpendidikan SLTA sebesar $25 \%$. Sedangkan S-III dan S1 memiliki nilai motivasi yang paling rendah. Hal yang mendasar sesuai hasil penelitian. Bahwa umumnya pegawai yang berpendidikan S2 sudah merasa cukup terjamin hari tuanya serta merasa puas bekerja di organisasi tersebut. Sedangkan bagi yang berpendidikan S1 dan D-III masih merasa belum cukup terjamin hari tuanya. Sementara pegawai yang berpendidikan SLTA motivasi untuk menyelesaikan pekerjaan tepat pada waktunya memilki tingkat motivasi yang tinggi.

Dari hasil-hasil penelitian mengenai motivasi pegawai tersebut, perlu dipahami bahwa, walaupun faktor motivasi memiliki pengaruh yang tidak terlalu besar terhadap karier, namun terbukti bahwa faktor motivasi juga memiliki peranan yang sangat penting sekali dalam rangka mencapai keberhasilan karier. Kondisi tersebut sesuai dengan yang dinyatakan oleh Umam (2010: 159), bahwa kuat dan lemahnya motivasi kerja seseorang ikut menentukan besar kecilnya prestasi orang tersebut. Oleh karena itu para pegawai harus mampu menjaga dan meningkatkan motivasi dalam bekerja.

Akhir daripada pembahasan hasil penelitian menegaskan bahwa adanya perspektif pada diri pegawai akan berkaitan dengan konsep diri yang berdasarkan daya motivasi dan kemampuan pegawai untuk menunjukkan sikap kerja pegawai itu sendiri.
Motivasi juga semakin dianggap penting, hal tersebut dikarenakan bahwa pada dasarnya pengangkatan pegawai negeri sipil dalam jabatan tertentu dipengaruhi atas dasar perbandingan yang obyektif antara kompetensi, kualifikasi, dan persyaratan yang dibutuhkan oleh jabatan organisasi dengan melihat kompetensi, kualifikasi, dan persyaratan yang dimiliki oleh individu pegawai. Oleh karena itu jelas sekali bahwa karir bukan hanya menjadi kewajiban organisasi semata dalam pengelolaannya, namun karir juga menjadi tanggungjawab setiap diri individu pegawai.

\section{SIMPULAN}

Berdasarkan hasil penelitian mengenai pengaruh perspektif dan motivasi pegawai negeri sipil terhadap karir di Lembaga Kesehatan Penerbangan dan Ruang Angkasa (Lakepra) Saryanto, maka diperoleh kesimpulan sebagai berikut: 1). Secara parsial perspektif pegawai negeri sipil berpengaruh positif dan signifikan terhadap karier di Lakespra Saryanto. Besaran sumbangan pengaruh faktor perspektif terhadap karier sebesar $26.9 \%$. 2). Secara parsial motivasi pegawai negeri sipil berpengaruh positif dan signifikan terhadap karir di Lakespra Saryanto. Besaran sumbangan pengaruh faktor motivasi terhadap karier sebesar 32.3 \%. 3). Secara bersama-sama perspektif dan motivasi pegawai negeri sipil berpengaruh positif dan signifikan terhadap karir di Lakespra Saryanto. Besaran sumbangan pengaruh faktor perspektif dan motivasi secara simultan terhadap karier sebesar $\mathbf{5 9 . 2}$ $\%$.

Hasil kesimpulan tersebut memberikan suatu skema dan pemahaman bahwa faktor perspektif dan faktor motivasi memiliki peranan yang sangat penting sekali dalam mendukung pencapaian karir pegawai di organisasi.

\section{DAFTAR PUSTAKA}

Akhmad, Jaenudin. 2012. Psikologi Industri.: Lentera Ilmu Cendikia, Jakarta. 
Ardianto, Elvinaro dan Q-Anees, Bambang. 2014. Filsafat Ilmu Komunikasi.: Simbiosa Rekatama Media, Bandung.

Arikunto, Suharsimi. 2013. Prosedur Penelitian Suatu Pendekatan Praktik.: PT. Rineka Cipta, Jakarta.

Effendi, Usman E. dan Praja S. Juhaya. 2012. Pengantar Psikologi.: CV. Angkasa, Bandung.

Fahmi, Irham. 2016. Teori dan Teknik Pengambilan keputusan Kualitatif dan Kuantitatif.: PT. Raja Grafindo Persada, Depok.

Fajar, Siti Al, dan Heru, Tri. 2015. Manajemen Sumber Daya Manusia Sebagai Dasar Meraih Keunggulan Bersaing.: Unit Penerbitan dan Percetakan Sekolah Tinggi Ilmu Manajemen YKPN, Yogyakarta.

Ghozali, Imam. 2016. Aplikasi Analisis Multivariete Dengan Program IBM SPSS 23.: Badan Penerbit Universitas Diponegoro, Semarang.

Handoko, T. Hani 2011. Manajemen Personalia dan Sumberdaya Manusia.: BPFE-Yogyakarta.

Hasibuan, Malayu SP. 2009. Manajemen Sumber Daya Manusia.: Bumi Aksara, Jakarta.

Mangkunegara, Anwar Prabu. 2013. Manajemen Sumber Daya Manusia.: PT. Remaja Rosdakarya, Bandung. 2014. Evaluasi

Kinerja SDM.: PT. Refika Aditama, Bandung.

Manullang, M. 2008. Manajemen Personalia.: Gadjah Mada University Press, Yogyakarta.

Mondy, R. Wayne. 2008. Manajemen Sumber Daya Manusia.: Erlangga, Jakarta.

Munandar, Ashar Sunyoto. 2014. Psikologi Industri dan Organisasi.: Penerbit Universitas Indonesia (UI-Press), Jakarta.

Peraturan Menteri Pertahanan Nomor 22 Tahun 2010.
Rakhmat, Jalaluddin. 2011. Psikologi Komunikas.: PT. Remaja Rosdakarya, Bandung.

Renaldi, Brisma. 2009. Pola Pikir Pegawai Negeri Sipil.: Lembaga Adminitrasi Negara Republik Indonesia.

Rivai, Veitzal Zainal. Mansyur Ramly, Thoby Mutis dan Willy Arafah. 2015. Manajemen Sumber Daya Manusia Untuk Perusahaan : Dari Teori ke Praktik.: Raja Grafindo Persada, Jakarta.

Sarwono, Sarlito W. 2010. Pengantar Psikologi Umum.: PT. Raja Grafindo Persada, Jakarta.

Siagian, Sondang P. 2016. Manajemen Sumber Daya Manusia.: PT. Bumi Aksara, Jakarta.

Simamora, Henry 2015. Manajemen Sumber Daya Manusia.: Bagian Penerbitan Sekolah Tinggi Ilmu Ekonomi YKPN, Yogyakarta.

Sugiyono. 2014. Metode Penelitian Manajemen.: CV. Alfabeta.: Bandung. 2014. Metode Penelitian Kuantitatif, Kualitatif dan R\&D.: CV. Alfabeta, Bandung. 2015. Statistika Untuk Penelitian.:

CV. Alfabeta, Bandung.

Suryana. 2006. Kewirausahaan, Kiat dan Proses Menuju Sukses.: Salemba Empat, Jakarta.

Syarief, Reza M. 2008. Life Excellence, Menuju Hidup Lebih Baik.: Prestasi Kelompok Gema Insani, Depok.

Umar, Husein. 2013. Desain Penelitian MSDM dan Perilaku Karyawan Paradigma Positivistik dan Berbasis Pemecahan Masalah.: PT. Raja Grafindo Persada, Depok.

Wahana Komputer. 2012. Shortcourse Series SPSS 20.: CV. Andi Offset, Yogyakarta 